\title{
PEDAGOGICAL PECULIARITIES OF FORMING LINGUOCULTURAL COMPETENCE OF HIGHER EDUCATION STUDENTS IN KARAKALPAKSTAN
}

\author{
Zoya Sarsenbaeva Jangabay qizi \\ PhD Student, Nukus State Pedagogical Institute Named After Ajiniyaz Nukus, 230113, \\ Karakalpakstan, Uzbekistan
}

Article DOI: https://doi.org/10.36713/epra7663

DOI No: 10.36713/epra7663

\begin{abstract}
The article deals with the pedagogical importance and peculiarities of linguocultural competence and ways of forming linguocultural competence of higher education students in Karakalpakstan. The article gives students a clear explanation of the linguocultural competence and its interactions throughout its development, and improving linguocultural competence with the help of materials in the English and Karakalpak languages. In the article, empirical, qualitative, comparative, and semantic methods analyses have been used. Furthermore, interviews for the research problem were based upon fifteen questions and questionnaires were administered and interviews were conducted. The author notes that through learning national proverbs based on a comparative analysis, students will be able to learn national and foreign culture, and develop linguocultural competence as well.

KEY WORDS: competence, linguocultural competence, Karakalpak language, foreign language (FL), classification, national proverbs, comparative analysis.
\end{abstract}

\section{INTRODUCTION}

Research questions

(i) What does Linguoculturology deal with?

(ii) What impact comparative study of Proverbs (Paremiology) does make on Karakalpak students?

(iii) How does the educational system of Uzbekistan include the teaching of foreign languages?

(iv) What are the ways of forming students' Linguocultural competence?

Currently, it is important to take into consideration how technology is changing the way we teach and learn, especially in preparing highly qualified professional future teachers, leading to the emergence of a new pedagogy. In Uzbekistan, the reforms in foreign language teaching mainly touch upon teaching English as a foreign language in all levels and stages of education. In the world the Common European Framework of Reference (CEFR) is the most comprehensive, and the most widely used set of foreign language education standards, and in Uzbekistan CEFR is used as the main framework to be adopted in developing the national standard. Linguoculturology is a new branch of science, deals with manifestations of culture of different nations, and are reflected in the language. This new field of linguistic research represents a merger of two distinct sub disciplines of linguistics that are sociolinguistics and culturology. Much interest in culturology and its actual rise from the state of amateur speculation to a serious science date from the late $20^{\text {th }}$ century. Researches in this field mainly use sociolinguistic methods to explain different language phenomena. This approach was useful when language internal data was unable to account for some inexplicable facts. Linguoculturology is aimed at examining linguistic units in connection with historical and social development of the nation at different periods. Thus, Linguoculturology ensures general broad comprehension of the language as a complex system.

According to the Presidential Decree of the President of the Republic of Uzbekistan Sh.M. Mirziyoyev (2017) "On the State Program for Implementation of the Action Strategy on five priority areas of development of the Republic of Uzbekistan in 2017-2021" was adopted on January 22, 2018 named "Development of Education and Science", has been noted that it is significant to make "maintaining the policies aimed at further improving the system of continuous education, increasing access 
to quality education, training of qualified personnel in accordance with the demand of the labor market".

According to Byram (1997), he states that when people are talking to each other their social identities are a main part of the social interaction between them. In language teaching the concept of communicative competence takes this into consideration by emphasizing that language learners need to acquire not just grammatical competence but also the knowledge of what is appropriate language. In teaching English as a foreign language Linguoculturological approach mainly focuses on the semantic concept. Through this angle the process of learning the English language implies not only traditional study of phonetics, grammar, and vocabulary, but also the English language mastering through its national concepts. In this case, this process can create opportunities for learners to acquire ethno cultural knowledge of language that is being learned, culture and history, resulting in formation of linguocultural competence.

In Zimnyaya's words (2003), the concept competency is defined as intellectual and personal ability of an individual to practical activities, and competence as content's component of the given ability in the form of knowledge, and skills. Linguoculturology deals with lots of issues related to the language, such as the role of culture in formation of linguistic concepts, connection between the linguistic symbol and cultural sense of a word. It is important to identify cultural semantics which could be obtained from the interaction of two different fields that are language and culture. When we analyze the relationship between Language and culture, we can see that language shapes cultural interactions and cultural interactions shape language. Therefore, we should consider that the relationship of language to culture can involve many contradictory problems. For instance, a problem might happen when cultural information of linguistic items mainly acquires some hidden implication as the meanings of some words sometimes can change in course of time.

\section{LITERATURE REVIEW}

The word competence is a set of abilities, considered as final qualitative result of education and there are various types of competencies such as intellectual, methodological, personal, social, sociocultural, and communicative competence. To develop interpretive, interactive and productive competencies, learners need to develop supporting competencies. One of the most essential supporting competencies is linguistic competency. This competency includes the learning and mastery of grammar, pronunciation and the vocabulary needed in a given context. This classification of competencies is quite understandable but it should be completed. However, it is assumed that linguistic awareness may never be sufficient unless it is along with cultural awareness. Therefore, linguocultural, socio-cultural and non-verbal competences should be taken into consideration. Also, as Chinh (2013) pointed out that culture governs the behaviors which a person encounters and it also governs how a person acts in or reacts to certain situations. Cultures have different ways of practices that indisputably reflect verbal and nonverbal language problems.

\section{METHODOLOGY}

Currently, teaching vocabulary has become essential in language teaching and learning based on a comparative method analysis, particularly in the latest years. Phraseology has been one of the major components of language due to its high and spontaneous occurrence in daily communication. Hill (2001) states that mental lexicon on an individual is in great deal consisting of a vast repertoire of learned phrases of varying degrees of fixedness. This means that such fixed expressions are usually considered rather difficult especially for foreign language learners owing to two main reasons: their cultural backgrounds and their conventionality, normally significantly different from the learners' mother language. However, it is obvious that they are primary to achieve a good command of the language, and ultimately, a proper communicative competence. Therefore, we can state that language is not isolated, but a social and cultural tool.

In Karakalpak auditoriums, English is taught as a foreign language and English as a specific purpose for some specialties. Course books and textbooks on both the teaching of native and foreign languages usually include at least some lists of proverbs. A content related curriculum program with a list of Karakalpak proverbs with translations in other foreign languages should be created in order to reach the aim, accompanying by providing a series of exercises and activities that will help the learner to discover what each proverb means and how to apply it in particular situations. And the program based on semantic-structural analysis of proverbs can be used in teaching the subject Pedagogy, especially in the chapter Didactics. When students learn proverbs, they can employ them in meaningful contexts, and they act according to wisdom, thus, they can deal with abstract and metaphorical proverbs as rules of moral conduct. Also, proverbs can play a major role in the teaching of English as a foreign language, where they are included as part of metaphorical and cultural teaching and learning. As teachers plan the curriculum and devise textbooks for teaching English as a foreign language (EFL), they should choose those proverbs for inclusion that part of the AngloAmerican paremiological minimum. It is the proverbs that are in use today that ought to be taught, as Michael Abadi (2000) has argued in his survey of 
"Proverbs as ESL (English as Second Language) Curriculum". Proverbs have a great potential in developing linguocultural competence and all kinds of speech activity. Proverbs could be used at EFL classes as a means of improving skills in speaking and writing, in listening and reading.

\section{RESULTS}

The analysis of the test results has shown that more than $90 \%$ of students of General pedagogy and psychology and Methods of teaching Physics departments have difficulties in the learning process at the institution. The main reason for the difficulties was insufficient knowledge of English, which was indicated by $62 \%$ of respondents. $32 \%$ of respondents indicated the lack of educational materials and literature adapted for the students. Learning of a large number of new words in English with equivalents in
Karakalpak within a short time was the cause of learning difficulties for $45 \%$ of students. The program of educational process, unusual for the students, caused difficulties for $12 \%$ of students. About $15 \%$ of students pointed out that they had spent too much time for their self study of incomprehensible material. About $15 \%$ of respondents said that their poor training and discouragement was the cause of problems in their study. Only $5 \%$ of students reported no difficulties in their learning. We found out the following educational forms used in teaching Pedagogy (Didactics) in the class: Teacher's monologue (at lectures); Discussion; solving problems and doing written exercises (in practical classes, when performing tests and individual assignments); Presentations, media.

Table 1: Questionnaire for students of higher educational institutions in Karakalpakstan on linguoculturology.

\begin{tabular}{|c|c|c|}
\hline № & Karakalpak & English \\
\hline 1 & Siz neshinshi kursta tálim almaqtasız? & What course are you in? \\
\hline 2 & Siz "mádeniyat" degende neni túsinesiz? & What do you understand by "culture"? \\
\hline 3 & $\begin{array}{l}\text { Siz lingvomádeniyat degende neni túsinesiz? } \\
\text { (Lingvokul'turologiya) }\end{array}$ & What do you understand by "linguoculturology"? \\
\hline 4 & $\begin{array}{l}\text { Lingvomádeniy kompetenciya degende neni } \\
\text { túsinesiz? }\end{array}$ & What is linguocultural competence? \\
\hline 5 & $\begin{array}{l}\text { Lingvomádeniy kompetenciyanı́n Lingvistikalıq, } \\
\text { Sotsio - lingvistikalıq, Sotsio-mádeniy hám } \\
\text { Pragmatikalıq kompetenciyalar menen baylanısı } \\
\text { qanday? }\end{array}$ & $\begin{array}{l}\text { How is linguocultural competence related to } \\
\text { Linguistic, Socio-Linguistic, Socio-Cultural and } \\
\text { Pragmatic competencies? }\end{array}$ \\
\hline 6 & $\begin{array}{l}\text { Siz pedagogikalıq sheberlikti úyreniwdi qay } \\
\text { dárejede nátiyjeli dep esaplaysız? }\end{array}$ & $\begin{array}{l}\text { How do you think learning pedagogical skills is } \\
\text { effective? }\end{array}$ \\
\hline 7 & 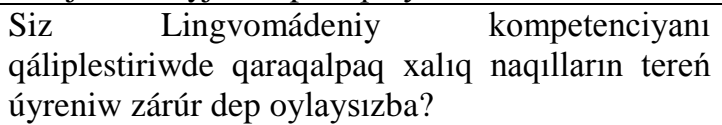 & $\begin{array}{l}\text { Do you think that it is necessary to study Karakalpak } \\
\text { national proverbs in depth in the formation of } \\
\text { linguocultural competence? }\end{array}$ \\
\hline 8 & $\begin{array}{l}\text { Siz qaraqalpaq xalıq naqılların inglis tilindegi } \\
\text { xalıq naqıllari menen salıstırmalı úyreniw } \\
\text { áhmiyetli dep esaplaysızba? }\end{array}$ & $\begin{array}{l}\text { Do you think that it is important to study Karakalpak } \\
\text { national proverbs with English national proverbs } \\
\text { comparatively? }\end{array}$ \\
\hline 9 & Siz frazeologizm degende neni túsinesiz? & What do you mean by phraseologism (phraseology)? \\
\hline 10 & $\begin{array}{l}\text { Siz kúndelik turmısta, sóylesiwde kóbinese } \\
\text { qanday frazeologiyalıq birliklerdi qollanasız? }\end{array}$ & $\begin{array}{l}\text { What phraseological units (or phrases) do you use } \\
\text { most often in everyday life? }\end{array}$ \\
\hline 11 & $\begin{array}{l}\text { Siz qaysı didaktikalıq miynetlerdi bilesiz hám } \\
\text { súyip oqıysız? }\end{array}$ & What didactic works do you know and like to read? \\
\hline 12 & $\begin{array}{l}\text { Siz Lingvomádeniy kompetenciyanı } \\
\text { qáliplestiriwde shet el mádeniyatın úyreniwdiń } \\
\text { áhmiyeti qay dárejede dep oylaysız? }\end{array}$ & $\begin{array}{l}\text { How do you think the study of foreign culture is } \\
\text { important in the formation of linguocultural } \\
\text { competence? }\end{array}$ \\
\hline 13 & $\begin{array}{l}\text { Házirgi rawajlanıp atırǵan } \begin{array}{r}\text { jámiyette, } \\
\text { mádeniyatlarara bilim hám } \\
\text { iyelewdiń áhmilikpelerdi }\end{array} \\
\text { kanday? }\end{array}$ & $\begin{array}{l}\text { What is the importance of acquiring intercultural } \\
\text { knowledge and skills in today's evolving society? }\end{array}$ \\
\hline 14 & $\begin{array}{l}\text { Siziń oqıtıwshıńı sabaq ótiw procesinde } \\
\text { (pedagogikalıq sheberlik) qanday pedagogikalıq } \\
\text { texnologiyalardı qollanadı? }\end{array}$ & $\begin{array}{l}\text { What modern pedagogical technologies does your } \\
\text { teacher use in the classroom (subject pedagogical } \\
\text { skills)? }\end{array}$ \\
\hline 15 & $\begin{array}{l}\text { Siziń oqıtıwshı́́ı sabaq ótiw procesinde, } \\
\text { lingvomádeniy kompetenciyanı rawajlandırıwda } \\
\text { qanday zamanagóy metodlardan paydalanadı? }\end{array}$ & $\begin{array}{l}\text { What modern methods does your teacher use during } \\
\text { the lesson to build linguocultural competence? }\end{array}$ \\
\hline
\end{tabular}


At the beginning, students used grammar translation method to learn proverbs and phrases that is a traditional method for students. However, it was difficult to find exact meaning of the phraseological units, proverbs into the Karakalpak language, thus the method was not useful in studying in some cases. The analysis shows that the total linguocultural competence level became significantly higher in the experimental group of students than in the control group. The results have shown that the use of three types of tasks at the lessons and two types of tests (online and in face-to-face classroom) in the self study has a significant impact on the development of formation of linguocultural competence in a discipline.

Furthermore, in the course of our study we tried to understand what students expect from teachers and what form of feedback they would prefer. Accordingly, $65 \%$ of respondents noted that it is important for them to receive feedback at the lessons, when the teacher checks their mistakes in pedagogical terms. About $23 \%$ of students said that it is better if the teacher explains their mistakes individually. About $12 \%$ said that it is enough for them when the teacher points out the mistakes to all group at the classroom board. These comments of students could be important for the work of the teacher.

Thus, we assume that forming students' linguocultural competence should be a critical aim of linguistic and non-linguistic classrooms, and teachers are emerged as essential players for accomplishing this purpose. Teaching foreign language can provide a chance for students to reflect their own language and culture through the experience with foreign language and culture (Byram, 1997. Furthermore, making additions to the program of the subject Pedagogy, and to introduce culture in both the foreign language classrooms and non-linguistic specialty classrooms could be efficient in improving students' linguocultural competence.

\section{DISCUSSION}

In 1985, T. Jumamuratov wrote RussianKarakalpak phraseologisms for school pupils, G. Aynazarova (2005) analyzed phraseological units related to lexicology, stylistic, and lexicography. G. Bekbergenova with B. Shaniyazov made and published a dictionary of Karakalpak proverbs with translations in the Russian language. Rich culture, history of Karakalpak people and national character can be described in the national proverbs. J. Eshbaev (1985) in his work in Karakalpak language, pointed out the relationship and differences between phraseological units and proverbs in the following way:
1. Proverbs are consisted of the main meaningful words without adding the supportive words. The structure of the proverbs can be similar to literary words. For example: "Qa'wmetine isengen, qa'ddin bu'gip o'tedi, Ko'pshilikke isengen, Maqsetine jetedi" (Meaning: A man who believes in many and achieves his goal).

2. In proverbs, the national character of people's life is very strong. For example: "Alg'is alg'an arimas, Qarg'is alg'an jarimas" (Meaning: He who takes people's dua (make dua-to pray for something) will live happily, he who is cursed (saying bad wishes) will be unhappy).

3. Each time the meaning of these words is determined from the second line, and this line completes the word in the first line. For example: "Ha'r kimdiki o'zine, Ay ko'riner ko'zine" (Meaning: Blood is thicker than water/The black crow thinks his own birds white).

4. The structure of proverbs is different, and repetition of words in the form of a compound word is can be seen in the following way. For example: "Tama tama ko'l boladi, Jawin jawsa sel boladi" (Meaning: Many a little makes a mickle).

5. Proverbs have the character of an exhortation in the sense of educating people with the norms of the best of humanity. For example: "Jamannan qash, Jaqsig'a jantas" (Meaning: Better be alone than be in the bad company).

6. Proverbs do not contain unimaginable superfluous words and they are mostly figurative in the literal sense. For example: "Qizim sag'an aytaman, Kelinim sen tin'la”, “So'z-gu'mis, U'ndemew-altin" (Meaning: My daughter, I tell you, my daughter-in-law, listen to me / Speech is silver but silence is gold).

7. In some articles, some components are repeated individually in the same state, while others are repeated using additions to the second component. The meaning of the first word is confirmed and complemented by the repeated second word. For example: “Ko'z ko’zge tu'sedi, Miyrim shapaat ju'zge tu'sedi", "Mal iyesine usaydi” (Meaning: Eye to eye, Mercy intercession to face / The work shows the workman).

8. Although some components in proverbs come in the possessive pronoun and are repeated several times in a proverb, their syntactic function will be different. For example: "El u'stine el kelse, ol eldin' da'wleti, El u'stinen el ketse, ol eldin' miyneti" (Meaning: When nations unite, it is the wealth of the people, When nations are scattered, it is the labor of the people). The word "el" is repeated many times in the proverb. However, with the word "el" (nation) in the first line, the word "el" in the second line is different in terms of within member of the sentence service. These words are interconnected 
by meaning. Many proverbs are lexically close to phraseological units and have a portable meaning. For instance: “Ko'rpen'e qarap ayag'in'di soz” or "Shaman'di bil" (means Stretch your legs according to the coverlet). However, proverbs like this should be considered as proverbs, not as phraseological units in terms of meaning. Because this proverb has full meaning of exhortation and it has the characteristics of other proverbs. Exact synonym or equivalent of all Karakalpak proverbs may not be found in the English language. However, in the examples above, we tried to find the meaning of Karakalpak proverbs in the English language.

\section{CONCLUSION}

The link language-culture is significant in foreign language education because culture plays a role in helping learners to be proficient in the target language (Nault, 2006). In addition, Alptekin (2002) states that: learning a foreign language becomes a kind of enculturation, where one acquires new cultural frames of reference and a new world view, reflecting those of the target language culture and its speakers. In the process of learning a foreign language, at the students learn a new world, a new culture. Language and culture have a function of communication because they both carry meanings. According to Kramsch (1998), culture learning is a process of interpretation and teaching cultural facts or information has not enabled learners to understand foreign attitudes, values, and mindsets.

In the foreign language learning, both students and teachers are required to be creative to apply different modern techniques of teaching English proverbs in comparison with Karakalpak language, with component expressing currency units (including proverbs and sayings). In order to study grammatical, semantic, structural, synonymous peculiarities of proverbs, phraseological units in the Karakalpak language thoroughly, literary works by famous national and English writers should be deeply analyzed. Thus, we put forward and came to the following conclusions:

1. Comparative cultural studies could make explicit connections between culture and society is an appropriate theoretical frame in which to study paremiology.

2. Culture based activities that are content related curriculum can help to overcome some linguistic challenges caused by learning phraseological expressions and proverbs in the two languages.

3. Comparative study of Proverbs (Paremiology) can have positive impact on Karakalpak students to improve linguocultural competence.

4. Contrastive and comparative study phraseological units (in the English and Karakalpak languages) could make impact on the development of speech competence, linguocultural competence, and improve cultural knowledge.

\section{LIMITATIONS AND SUGGESTIONS FOR FURTHER STUDY}

It should be pointed out that there are some limitations to the current study and propositions for future studies. This study aims at explaining how comparative study of paremiology work to improve Karakalpak students' linguocultural competence, but it cannot predict further impacts. Also, data interpretation is limited since it only includes a test and a questionnaire (Table 1). Increasing teachers' awareness of how relevant materials provided in classrooms is considered as significant as predicting its effect. In our further study, we will try to survey phraseological units comparatively by making a research analysis on the works and novels by Karakalpak writers such as T. Qayipbergenov, I. Yusupov and others. Also, in this article, data is based on two departments in Nukus state pedagogical institute, actually, not only students, but also, teacher participants should be selected randomly from other higher educational universities in the country.

\section{REFERENCES}

1. Alptekin, C. (2002). Toward intercultural communicative competence in ELT. ELT Journal, 56 (1), 57-64.

2. Bekbergenov, A. (1979). Qaraqalpaq tilinde so'zlerdin' jasaliwi. No'kis, Qaraqalpaqstan, 24.

3. Byram, M. (1997). Teaching and assessing intercultural communicative competence. Clevedon, Multilingual Matters LTD. 51-52.

4. Chinh, N. (2013). Cultural Diversity in English Language Teaching: Learners' Voices. English Language Teaching, 6(4), 1-8.

5. Eshbaev, J. (1985). Qaraqalpaq tilinin' qisqasha frazeologiyaliq so'zligi. No'kis., Qaraqalpaqstan baspasi, 18-25.

6. Djumamuratov, T. (1985). RusskoKarakalpakskiy frazeologicheskiy slovar' dlya shkol'nikov. Nukus, Karakalpakstan, 4-6.

7. Hill, J. (2001). Revising priorities: from grammatical failure to collocational success. In M. Lewis (Ed.). Teaching Collocation. Further Developments in the Lexical Approach. Ed. M. Lewis. London, Language teaching publications, pp. 47-49.

8. Kramsch, C. (1998). Language and Culture. Oxford: Oxford University Press.

9. Little, David. (2011). The Common European Framework of Reference for Languages: A research agenda. Language Teaching, 44(3), pp. 381-393.

10. Michael, C. Abadi. (2000). Proverbs: A Handbook Greenwood Publishing Group. 
11. Mieder, W. (1993). A proverb is a short sentence of Wisdom. (in Proverbs are Never out of Season).

12. Mirziyoyev, Sh. M. Action Strategy on five priority areas of development of the Republic of Uzbekistan in 2017-2021. https://mfa.uz/en/press/news. 2017.

13. Nault D. (2006). Going Global: Rethinking Culture Teaching in ELT Contexts Language. Culture and Curriculum, 19 (3), 314-328.

14. Sarsenbaeva, Z. J., Utebaev, T. T. (2020). Role of phraseology in developing communicative competence. EPRA International Journal of Multidisciplinary Research (IJMR), Volume: 6, Issue: $9 . \quad 47-53 . \quad$ doi: https://doi.org/10.36713/epra5111

15. Zimnyaya, I. A. (2003). Key Competences - New Paradigm of Educational Result. The Higher Education Today, (Vol 5), 34-42. 